deposited : First, the Lower Tertiaries, then Antwerp beds, then the Forest-bed, then Freshwater, then Fluvio-marine beds (including the Norwich Crag), then, in increasingly deeper water, the Chillesford Sands and Clays (including the Aldeby or Taylor's Crag), then the Marine pebbly-beds, and then the Lower Boulder-clay.

This succession of strata is borne out by the Mammalian remains, which are found in the Stone-bed upon the surface of the Chalk, which consists of flintsabraded from the Chalk. To such an extent has it been abraded by pluvial action and strong currents, that the Chalk at Hunstanton is reduced to nil ; and there can be no doubt it was once deposited there, as in other parts of the county, from the immense masses of Chalk-with-flints which are bouldered in that district.

The Mammalian remains consist of the Mastodon Arvernensis, the Elephas meridionalis, and a great variety of deer and other animals! The Mastodon is found in the Stone-bed associated with the Elephas meridionalis, but is not found in the Forest-bed. The Elephas meridionalis abounds in the Forest-bed, but has not been discovered in the Fresh-water, or Fluvio-marine beds, including the Norwich Crag. The so-called "Mammaliferous Crag," when united with the Stone-bed, was said to yield the Mastodon and Elephas meridionalis, but is now proved to be almost non-mammaliferous. Mr. Gunn also pointed out that the Bone-bed in Suffolk, upon the surface of the London Clay, containing the debris of Miocene-beds, is formed under similar conditions to the Stone-bed in Norfolk, and that the changes of the fauna indicate the long periods of time occupied by these several and respective formations.

\title{
CORRESPONDEITCE.
}

UNIO LIMOSUS, NILSSON, IN THE CRAG.

Sir,-It is so seldom that the opportunity offers of adding to the lists of fossils of the Post-glacial freshwater gravels, any species foreign to the present British fauna, that the discovery of a fine Unio may be regarded with some interest. The species referred to is the Unio limosus of Nilsson, Hist. Moll. Succ., p. 100, and is figured by Rossmasler, Iconographie, fig. 199. It lives in the rivers of Sweden, Denmark, and Northern Germany. My largest speci-

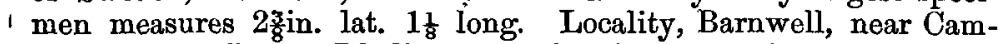
bridge. Mr. Jesson, I believe, was the discoverer of this interesting addition to our fossil tluviatile fauna. AlFRed BeLI.

\section{PURPURA LAPILLUS IN THE CORALLINE CRAG.}

Srn,- With reference to the article in your last Number, on a fossil Hydractinia from the Coralline Crag, by Dr. Allman, enveloping two specimens of Purpura lapillus, I would remind your readers that this Molluse is at present unknown from the Cor. Crag. Has Dr. Allman found it?

Skarles V. Wood.

Brentwood, Essex. 